\title{
THE STUDY ON PLASMIN IN CASES WITH CEREBRAL VASCULAR LESION
}

\author{
YUICHIRO GOTO, M.D.*, KEIICHI MURAKAMI, M.D. and \\ TOYOZO AIZAWA, M.D.** \\ Research Project on Plasmin and Antiplasmin \\ Department of Internal Medicine, School of \\ Medicine, Keio University
}

(Received for publication September 15, 1959)

The studies on plasmin system in the field of internal medicine have been made exclusively in hemorrhagic hematologic diseases up to date.

Recently, we are investigating on this enzyme system on the patient ailing cerebral vascular lesions, and will present some of our results in this paper.

\section{METHOD AND MATERIAL}

Materials: The number of cases studied up to date is 45 , involving both sexes aged from 45 to 71 years old.

The cases consist of 9 intracranial hemorrhages, 13 cerebral infarctions, 20 arteriosclerosis (including those with hypertension) and 3 retinal bleedings. All of the arteriosclerotic patients chosen for this survey reveal ophthalmoscopically moderate to severe retinal arteriolosclerosis. (K.W. Gr. II-III-IV)

Method: For the determination of plasmin activity, venous blood of patient was used. After withdrawal, the blood sample was immediately mixed with $1 / 10$ volume of $3.8 \%$ sodium citrate solution and kept at $4^{\circ} \mathrm{C}$ in a refrigerator. The routine method to determine the activity are as follows.

1) Whole clotolysis test (by Ratnoff's method) (1)

2) Euglobulin lysis test (by Lewis's method) (2)

3) Streptokinase activated plasmin activity (whole plasmin unit) (Colgan's method) (3)

4) Quantitative determination of fibrinogen(4)

These methods were partially modified for the use at our technical center. The criterion for the plasmin activity is as follows.

As to whole clotolysis test, occurrence of this phenomen within 3 days was

* Instructor in Internal Medicine.

** Professor of Internal Medicine. 
interpreted as "accelerated" (positive), between the 4th and 6th day as "normal" and after the 7 th day as "prolonged."

In streptokinase activated plasmin activity, below $20 \mathrm{u}$. was interpreted as negative ( $(-)$, from 21 u. to $26 \mathrm{u}$. as $( \pm)$ and over $27 \mathrm{u}$. as positive $(+)$.

For euglobulin lysis test, below $0.7 \mathrm{u}$, was decided as negative above $1.0 \mathrm{u}$. as positive.

As to fibrinogen, below $2 \mathrm{mg} / \mathrm{ml}$ was considered to be decreased and above $4 \mathrm{mg} / \mathrm{ml}$ to be increased.

\section{RESULTS}

Results in 9 cases with intracranial hemorrhage (cerebral hemorrhage 8 and subarachnoid hemorrhage 1) are as follows. (Interval between the attack and blood sampling varied from 4 hours to 31 months).

With whole clotolysis test, plasmin activity normal 3 , increase $(t) 3$, decrease 2 , non examined 1 , streptokinase activated plasmin activity $(+) 4$, (士) 5, (-) 0. Euglobulin lysis test was negative in all examined cases. Fibrinogen normal 5 , decrease 2 and increase 2.

The case where plasmin activity was most remarkable was 59 years old male died one day after the attack of cerebral hemorrhage. In this case results were as follows; whole clotolysis test-3rd day $(+)$, streptokinase activated plasmin $-27.8 \mathrm{u}$. $(+)$, fibrinogen $-1.1 \mathrm{mg} / \mathrm{dl}$. (decreased). Euglobulin lysis test was not performed.

Of 3 cases with retinal bleeding, whole clotolysis test was normal in 1 case, prolonged in 2 cases. Streptokinase activated plasmin activity was ( + ) in 1 case, $( \pm)$ in 2 cases. Fibrinogen was normal in all cases.

of 13 cases wih cerebral infarction, whole clotolysis test was normal in 5 patients and prolonged in 7 cases. Streptokinase activated plasmin activity. was positive in only one case, $( \pm)$ in 11 cases and negative in 1 case. Euglobulin

Table 1

Activity of Blood Plasmin in Cases with Cerebral Vascular Lesion

\begin{tabular}{|c|c|c|c|c|c|c|c|c|c|c|c|}
\hline \multirow[b]{2}{*}{$\begin{array}{l}\text { Case } \\
\text { No. }\end{array}$} & \multirow[b]{2}{*}{ Name } & \multirow[b]{2}{*}{ Sex } & \multirow[b]{2}{*}{ Age } & \multirow[b]{2}{*}{ Diagnosis } & \multirow{2}{*}{\multicolumn{2}{|c|}{$\begin{array}{l}\text { Interval } \\
\text { from the } \\
\text { attack to } \\
\text { sampling }\end{array}$}} & \multicolumn{5}{|c|}{ Plasmin-Activity } \\
\hline & & & & & & & $\begin{array}{c}\text { Fibri- } \\
\text { nogen } \\
(\mathrm{mg} / \mathrm{ml})\end{array}$ & $\begin{array}{l}\text { Whole } \\
\text { clotolysis } \\
\text { (days) }\end{array}$ & $\begin{array}{l}\text { Whole } \\
\text { plasmin } \\
\text { (unit) }\end{array}$ & $\begin{array}{l}\text { Euglobu } \\
\text { lysis t } \\
\text { (unit }\end{array}$ & $\begin{array}{l}\text { ulin- } \\
\text { test } \\
\text { it) }\end{array}$ \\
\hline 15 & & $\mathrm{M}$ & 48 & $\begin{array}{l}\text { Cerebral } \\
\text { hemorrhage }\end{array}$ & & lonths & 2.8 & 10 & 25.64 & less than & 0.56 \\
\hline 16 & & $\mathrm{M}$ & 46 & $\|$ & 2 & $"$ & 3.0 & 9 & 30.30 & $"$ & 0.56 \\
\hline 20 & & M & 60 & "l & 10 & $"$ & 1.9 & 4 & 27.77 & $"$ & 0.56 \\
\hline 21 & & $\mathrm{M}$ & 64 & $"$ & 18 & $"$ & 3.1 & 4 & 25.64 & $" \prime$ & 0.56 \\
\hline 32 & & $\mathrm{M}$ & 62 & $"$ & 12 & $"$ & 4.4 & 3 & 27.80 & $" \prime$ & 0.56 \\
\hline
\end{tabular}




\begin{tabular}{|c|c|c|c|c|c|c|c|c|c|c|}
\hline \multirow[b]{2}{*}{$\begin{array}{l}\text { Case } \\
\text { No. }\end{array}$} & \multirow[b]{2}{*}{ Name } & \multirow[b]{2}{*}{ Sex } & \multirow[b]{2}{*}{ Age } & \multirow[b]{2}{*}{ Diagnosis } & \multirow{2}{*}{$\begin{array}{l}\text { Interval } \\
\text { from the } \\
\text { attack to } \\
\text { sampling }\end{array}$} & \multicolumn{5}{|c|}{ Plasmin-Activity } \\
\hline & & & & & & $\begin{array}{c}\text { Fibri- } \\
\text { nogen } \\
(\mathrm{mg} / \mathrm{ml})\end{array}$ & $\begin{array}{l}\text { Whole } \\
\text { clotolysis } \\
\text { (days) }\end{array}$ & $\begin{array}{l}\text { Whole } \\
\text { plasmin } \\
\text { (unit) }\end{array}$ & $\begin{array}{l}\text { Euglobu } \\
\text { lysis te } \\
\text { (unit }\end{array}$ & $\begin{array}{l}\text { ulin- } \\
\text { test } \\
\text { t) }\end{array}$ \\
\hline 36 & & M & 45 & $"$ & 1 day & 3.8 & 6 & 25.64 & $" \prime$ & 0.56 \\
\hline 37 & & M & 59 & $" l$ & 4 hours & 1.1 & 3 & 27.80 & - & - \\
\hline 106 & & $\mathrm{~F}$ & 52 & $"$ & 5 months & 2.4 & - & 22.22 & - & - \\
\hline 29 & & M & 44 & $\begin{array}{l}\text { Subarachnoid } \\
\text { hemorrhage }\end{array}$ & 4 days & 8.3 & 3 & 20.83 & less than & 0.56 \\
\hline 13 & & $\mathrm{~F}$ & 58 & $\begin{array}{l}\text { Retinal } \\
\text { bleeding }\end{array}$ & & 3.4 & 5 & 30.30 & $" \prime$ & 0.56 \\
\hline 14 & & $\mathrm{~F}$ & 57 & $\|$ & & 2.6 & 10 & 23.81 & $" 1$ & 0.56 \\
\hline 23 & & $\mathrm{~F}$ & 68 & $" \prime$ & & 3.2 & 8 & 24.69 & $"$ & 0.56 \\
\hline 2 & & M & 55 & $\begin{array}{l}\text { Cerebral } \\
\text { thrombosis }\end{array}$ & 19 months & 3.1 & 6 & 25.64 & $"$ & 0.56 \\
\hline 3 & & $\mathrm{M}$ & 71 & $\|$ & $" \prime$ & 2.7 & 6 & 25.64 & $" 1$ & 0.56 \\
\hline 4 & & M & 67 & $" \prime$ & $19 \quad "$ & 3.4 & 8 & 25.64 & $"$ & 0.56 \\
\hline 5 & & $\mathrm{M}$ & 63 & $"$ & $7 \quad 1$ & 2.8 & 8 & 28.98 & $" \prime$ & 0.56 \\
\hline 6 & & $\mathrm{M}$ & 64 & " & 4 & 4.5 & 7 & 19.61 & " & 0.56 \\
\hline 9 & & $\mathbf{M}$ & 60 & "I & 7 & 6.3 & 6 & 23.81 & $"$ & 0.56 \\
\hline 17 & & M & 60 & $\begin{array}{l}\text { Cerebral } \\
\text { embolism }\end{array}$ & $" \prime$ & 7.5 & 11 & 23.81 & $"$ & 0.56 \\
\hline 18 & & M & 66 & $\begin{array}{l}\text { Cerebral } \\
\text { thrombosis }\end{array}$ & 5 & 4.3 & 4 & 21.50 & $" \prime$ & 0.56 \\
\hline 19 & & M & 61 & $"$ & $31 \quad \prime \prime$ & 4.3 & 5 & 23.81 & $"$ & 0.56 \\
\hline 22 & & M & 58 & $"$ & 2 days & 3.5 & 9 & 23.81 & $"$ & 0.56 \\
\hline 25 & & M & 61 & $" \prime$ & 6 months & 4.2 & 9 & 20.83 & $"$ & 0.56 \\
\hline 105 & & $\mathrm{~F}$ & 63 & $"$ & $5 \quad \prime \prime$ & 2.8 & - & 25.04 & & 0.69 \\
\hline 39 & & $\mathrm{M}$ & 69 & "I & 1 day & 2.7 & 8 & 22.20 & less than & 0.56 \\
\hline 1 & & $\mathrm{M}$ & 67 & $\begin{array}{l}\text { Arteriosk- } \\
\text { lerosis }\end{array}$ & & 3.1 & 6 & 23.81 & $"$ & 0.56 \\
\hline 10 & & M & 63 & " & & 3.1 & 6 & 30.30 & $"$ & 0.56 \\
\hline 11 & & $F$ & 55 & $"$ & & 3.7 & 3 & 25.64 & $"$ & 0.56 \\
\hline 101 & & $\mathrm{~F}$ & 60 & $"$ & & 3.2 & 2 & 16.66 & " & 0.56 \\
\hline 102 & & $\mathbf{M}$ & 69 & $"$ & & 3.2 & 2 & 16.66 & $"$ & 0.56 \\
\hline 107 & & $\mathbf{F}$ & 54 & $"$ & & 3.1 & - & 19.61 & " & 0.56 \\
\hline 109 & & $\mathrm{~F}$ & 62 & $"$ & & 4.0 & - & 25.64 & & 0.57 \\
\hline 112 & & $F$ & 65 & $"$ & & 2.7 & - & 22.22 & less than & 0.56 \\
\hline 115 & & $\mathrm{~F}$ & 58 & " & & 2.5 & 9 & 23.81 & $"$ & 0.56 \\
\hline 116 & & $\mathbf{F}$ & 53 & $"$ & & 2.2 & 7 & 20.83 & $"$ & 0.56 \\
\hline 117 & & M & 65 & $"$ & & 3.8 & 4 & 10.41 & " & 0.56 \\
\hline 118 & & $\mathrm{M}$ & 49 & $" \prime$ & & 2.4 & 3 & 25.64 & $"$ & 0.56 \\
\hline 119 & & $\mathrm{~F}$ & 52 & $" \prime$ & & 2.9 & 4 & 17.54 & & 0.58 \\
\hline 121 & & $\mathrm{M}$ & 74 & " & & 2.8 & 3 & 25.64 & less than & 0.56 \\
\hline 122 & & $\mathbf{M}$ & 56 & $"$ & & 2.9 & 4 & 25.64 & " & 0.56 \\
\hline 123 & & $\mathrm{~F}$ & 60 & $" \prime$ & & 3.0 & 3 & 23.81 & $" \prime$ & 0.56 \\
\hline 124 & & $\mathbf{M}$ & 48 & $" \prime$ & & 3.1 & 2 & 30.30 & $" \prime$ & 0.56 \\
\hline 125 & & $\mathbf{F}$ & 59 & $" \prime$ & & 2.7 & 6 & 27.77 & $" \prime$ & 0.56 \\
\hline 126 & & $\mathrm{~F}$ & 47 & $"$ & & 2.4 & 7 & 22.22 & $" \prime$ & 0.56 \\
\hline 27 & & $\mathrm{~F}$ & 56 & $"$ & & 4.1 & 4 & 23.81 & $"$ & 0.56 \\
\hline
\end{tabular}


Table 2

Activity of Blood Plasmin in Cerebral Vascular Disease

\begin{tabular}{|c|c|c|c|c|c|c|c|c|c|c|}
\hline \multirow[b]{2}{*}{ Diagnosis } & \multirow{2}{*}{$\begin{array}{c}\text { Number } \\
\text { of } \\
\text { cases }\end{array}$} & \multicolumn{3}{|c|}{ Fibrinogen } & \multicolumn{3}{|c|}{ Whole clotolysis } & \multirow{2}{*}{$\begin{array}{l}\text { Whole } \\
\text { plasmin } \\
+ \pm-\end{array}$} & \multirow{2}{*}{\multicolumn{2}{|c|}{$\begin{array}{l}\text { Euglobulin- } \\
\text { lysis test } \\
+\quad-\end{array}$}} \\
\hline & & $\begin{array}{c}\text { Decr- } \\
\text { ease }\end{array}$ & $\begin{array}{l}\text { Nor- } \\
\text { mal }\end{array}$ & $\begin{array}{l}\text { Incr- } \\
\text { ease }\end{array}$ & $\begin{array}{l}\text { Accel- } \\
\text { erated }\end{array}$ & $\begin{array}{l}\text { Nor- } \\
\text { mal }\end{array}$ & $\begin{array}{c}\text { Prolo- } \\
\text { nged }\end{array}$ & & & \\
\hline $\begin{array}{l}\text { Intracranial } \\
\text { hemorrhage }\end{array}$ & 9 & 2 & 5 & 2 & 3 & 3 & 2 & 45 & 0 & 9 \\
\hline $\begin{array}{l}\text { Retinal } \\
\text { bleeding }\end{array}$ & 3 & 0 & 3 & 0 & 0 & 1 & 2 & 12 & 0 & 3 \\
\hline $\begin{array}{l}\text { Cerebral } \\
\text { infarction }\end{array}$ & 13 & 0 & 7 & 6 & 0 & 5 & 7 & 111 & 0 & 13 \\
\hline $\begin{array}{l}\text { Arterio- } \\
\text { sclerosis }\end{array}$ & 20 & 0 & 19 & 1 & 7 & 7 & 3 & 312 & 0 & 20 \\
\hline
\end{tabular}

lysis test was negative in all cases. Fibrinogen normal 7, increase 6 .

Of 20 cases with arteriosclerosis, whole clotolysis was accelerated in 7 cases, normal in 7 cases, prolonged in 3 cases. Streptokinase activated plasmin activity was $( \pm)$ in 12 cases, $(+)$ in 3 cases and $(-)$ in 5 cases. Fibrinogen was normal in 19 cases, increased in 1 case.

\section{DISCUSSION AND SUMMARY}

Comparing the result in cases with cerebral hemorrhage to those in cases with cerebral infarction, in the former, whole clotolysis test is positive (accelerated) in one third of the cases, streptokinase activated plasmin activity is positive in about half of the cases and none of them is negative, while in the latter, whole clotolysis test is not accelerated in any cases, but is prolonged in 7 cases, streptokinase activated plasmin activity is $( \pm)$ in the majority of the cases and $(+)$ in only 1 case.

It is a very interesting fact that, in the cases of so called cerebral apoplexy, the value of whole clotolysis test and whole plasmin show a special tendence for hemorrhage and infarction respectively.

Plasmin was positive not in all cases with hemorrhage. This is probably due to the interval between the attack and blood sampling or to some other factors.

In cases with arteriosclerosis (including those hypertension) as the control for the cases with apoplexy, it was remarkable that streptokinase activated plasmin was negative in one fourth of the cases. On the other hand, whole clotolysis test was accelerated in several cases. These cases are considered very interesting as to the prognosis for the cerebral apoplexy, and beeing followed up carefully at our clinic. 
In conclusion, a definate relationship between cerebral vascular lesion, particularly intracranial hemorrhage and plasmin activity was suggested.

We are planning to make further investigation in more number of case as to the change of plasmin level in relation with time from attack and so on.

We wish to express our thanks to S. Okamoto, M.D., Professor of Physiology, Kobe Medical College.

We also appreciate the staff of the Technical Center of Research Project on Plasmin, Department of Physiology, Keio University School of Medicine.

\section{REFERENCES}

1. Ratnoff, O. D.: Bull. Johns Hopkins Hospital, 84:29, 1949.

2. Lewis, J. H. and Ferguson, J. H.: J. clin. Invest., 29:486, 1950.

3. Colgan, J., Gafes, E. and Miller, L. L.: J. exp. Med. 95:531, 1952.

4. Gram, H. C.: Die Eiweiss Koerper des Blutplasmas, Theodor Steinkopf, Dresden \& Leipzig, 1938, p. 102. 